\title{
SME international opportunity scouting-empirical insights on its determinants and outcomes
}

\author{
Mikael Hilmersson $^{1} \cdot$ Stylianos Papaioannou $^{2}$
}

Published online: 11 June 2015

(C) Springer Science+Business Media New York 2015

\begin{abstract}
International opportunities are the catalysts of SME internationalization. Our knowledge regarding the role of international opportunities in internationalization is undisputable, yet our understanding of the underlying mechanisms of international opportunity development remains inadequate. In this paper, we seek to address this shortcoming in the literature by answering the following research questions: how do internal and external factors influence the international opportunity scouting of SMEs, and what are the effects of the international opportunity scouting strategy in the internationalization of the firm? From a case study of nine Swedish SMEs, the authors develop propositions on the interplay between the theoretical constructs: international experience, network structure, international opportunity scouting, and international opportunity novelty. We propose that the greater the international experience of the SME, the more systematically the SME will scout for international opportunities; the more closed the network the SME is embedded in, the more systematically the SME will scout for international opportunities; and the more systematically the SME scouts for international opportunities, the lower the novelty of the opportunities identified by the SME. These findings come with implications for theory as well as for SME managers.
\end{abstract}

Keywords International experience $\cdot$ Network structure $\cdot$ Opportunity $\cdot$ Scouting . Opportunity novelty $\cdot \mathrm{SME} \cdot$ Internationalization

Mikael Hilmersson

mikael.hilmersson@hh.se

Stylianos Papaioannou

stylianos.papaioannou@miun.se

1 School of Business and Engineering, Halmstad University, 30118 Halmstad, Sweden

2 Department of Social Sciences, Business Administration, Mid Sweden University, 851

70 Sundsvall, Sweden 


\section{Introduction}

Research in the field of international entrepreneurship has shown that the discovery, enactment, evaluation, and exploitation of international opportunities are central to our understanding of firm internationalization (Mainela et al. 2014; Johanson and Vahlne 2009; Schweizer et al. 2010).). As a consequence, the internationalization of the firm has been described as a process of recognition and exploitation of entrepreneurial opportunities that lead to new international market entry (McDougall-Covin et al. 2014; Ellis 2011; Chandra et al. 2009).

From research on international opportunities, we know that the international opportunity development process has internal and external determinants (Mainela et al. 2014). Contributions regarding the internal determinants were provided by Chandra et al. (2009), who proposed that the degree of international experience influences the international opportunity search behavior of the firm. Johanson and Vahlne (2009) and Schweizer et al. (2010) revealed that the international experience of the firm is positively related to the ability of developing international opportunities. Finally, Crick and Spence (2005) showed that managers' entrepreneurial orientation plays a central role in the international opportunity development process. Contributions to the external determinants have been provided by Johanson and Vahlne (2009), who disclosed that the network position of the firm influences the international opportunity process. Similar findings were presented by Kontinen and Ojala (2011) as well as Chandra et al. (2009), who showed that the network ties of the firm influence the opportunity recognition process. Additionally, Ellis (2011) and Komulainen et al. (2006) showed that the social network of the entrepreneur is an important determinant of the international opportunity development process.

Less, however, is known about the development of international opportunities. Even though there is a consensus that international opportunities trigger, catalyze, and drive the international expansion of the firm, few studies have focused on how these opportunities are developed and why certain firms are better equipped than others in developing them (Butler et al. 2010). As a matter of fact, few studies have paid attention to the process of international opportunity development (Chandra et al. 2009; Johanson and Vahlne 2006). As a consequence, our knowledge regarding the underlying mechanism and dynamics of the international opportunity development process remain inadequate (Ellis 2011).

To develop knowledge regarding the international opportunity development of SMEs, we find inspiration from Hilmersson (2011), who introduced the concept of international opportunity scouting which refers to the strategic behavior of the international opportunity development process. According to this view, international opportunity development involves opportunities that are exogenous to the individual and endogenous outcomes of the entrepreneurial process (Sarasvathy et al. 2014). We argue that it is likely that the scouting strategy followed by the SME will have consequences for the impact and novelty of the opportunities developed. To advance knowledge in this field, we seek to establish the relationship between the concepts firm international experience, business network characteristics, international opportunity scouting, and international opportunity novelty. More precisely, our article seeks to answer the research questions: (a) how do internal and external factors influence the international opportunity scouting of SMEs, and (b) what are 
the effects of the international opportunity scouting strategy in the internationalization of the firm.

We argue that the development of knowledge in this field is of importance for both theoretical advancement and practitioners. First, we need to develop an in-depth knowledge about why certain firms are better equipped in developing international opportunities than others. We also need to know whether certain opportunity development strategies lead to heterogeneous outcomes. Second, for practitioners, this research should be of interest as it sheds light on how to design strategies for international opportunity development. Particularly, our article reveals how these strategies should be adapted to the internal and external prerequisites of the firm to increase the likelihood that the international growth ambitions of the firm are achieved.

The subsequent sections of our article are structured as follows. First, we present the theoretical background of our research. Then, we account for the case study methodology and our strategy for data analysis. An empirical descriptive section follows the "Method" section. Detailed information is provided on two cases whereas the data for the analysis and conclusions comes from nine cases. The data is condensed into an intra-case analysis, which is followed by our cross-case analysis. Based on the crosscase analysis, we generate propositions. The paper ends with our conclusions, the managerial implications, and our suggestions for further research.

\section{Theory}

\section{An opportunity-based view on internationalization}

Recent research on the internationalization process of the firm has sought to conceptualize the internationalization process as an international opportunity development process in business networks. According to this view, internationalization is the consequence of firms' actions to establish relationships and strengthen network positions (Johanson and Vahlne 2009). In this process, firms establish new positions, develop old positions, or increase the coordination between positions in a network. According to Chetty and Blankenburg-Holm (2000), firms move between these categories by extending their networks, a strategic change which is influenced by the SME's business relationships (Agndal and Chetty 2007) and its activities in the domestic network (Blomstermo et al. 2004). This implies that the international network extension process is incremental, where critical events in the process are dependent on either the firm's business network or the experiential knowledge base possessed by the firm (Hilmersson and Jansson 2012b). Experiential knowledge is important because it reduces uncertainty about further commitment (Hilmersson and Jansson 2012a; Johanson and Vahlne 2009, 1977) and enables firms to discover opportunities for further expansion (Hohenthal et al. 2003; Johanson and Vahlne 2009). Thus, internationalization of the firm can be seen as a process of international opportunity development where the identification and exploitation of international opportunities is the central driver of the international expansion of the firm (Ellis 2011). How such opportunities are recognized, identified, and created is then a central aspect of the critical first phase of the internationalization process that has been described as an 
underdeveloped phase in internationalization theory (Johanson and Vahlne 2003, 2006).

Before the development of an opportunity, firms look for promising information in their external environment. Hilmersson (2011) described this process as comparable to a professional sports club scouting for talented players. Thus, the scouting behavior of the firm can be very systematic where the firm is scouting for opportunities similar to what previously have been successful, or it can be more open-minded where a less systematic approach is followed. The starting point of the firms is the previous international experiences and their stock of knowledge. They compare information from the external environment, trying to match any new information with promising patterns from their past experiences. When they track a potentially promising opportunity, firms make the first contact with the new actors of the business network in order to establish a relationship. Thus, they view the opportunity identification and development process as an act of opportunity scouting.

\section{Business network characteristics}

Initiated by the publication of two book chapters (Johanson and Mattsson 1988; Johanson and Vahlne 1990, 2009), business network theory has emerged as one of the dominant schools to explain and understand firms' internationalization. This seems particularly important in the resource-constrained SME, which often is dependent on other actors. The network theory of internationalization builds on the idea that firms tend to develop long-lasting relationships with customers and suppliers. These relationships, in turn, are linked and connected with each other, meaning that the market tends to have a structure looking like a network. Internationalization in general and foreign market entry in particular are, according to this perspective, processes where the entering SME takes a position in the part of the network which is to be found in the foreign market; thus, the entering SME has to develop completely new relationships with customers and suppliers or break existing relationships and replace suppliers' or customers' positions in the network.

Whereas this perspective underlines that the network of the firm is an important factor explaining the internationalization of the firm, entrepreneurship research (e.g., Johannisson 1996) has shown that the social network of the entrepreneur is also an important determinant of the growth of the firm. According to Nahapiet and Ghoshal (1998), knowledge is socially embedded, residing in situations and relationships. In order to gain access to exogenous resources and information, entrepreneurs therefore rely on their social relationships and network (Ellis 2011). Since information is spread unevenly among the actors in the social network, the entrepreneur aims to be the first to obtain information and recognize new opportunities (Ellis 2011). Thus, interpersonal and inter-organizational relationships are considered to be the media through which entrepreneurs and companies in turn gain access to a variety of resources, information, and advice. Entrepreneurs consistently use networks to get ideas and gather information to recognize entrepreneurial opportunities (Hoang and Antoncic 2003).

In a wider perspective, no network is market-specific, but networks overlap country borders, which means that the whole global market is a network of relationships. In an internationalization respect, this means that the structure and quality of the SME's 
network will be a prerequisite for international expansion. We use three dimensions to examine the network of the firm. First, closure refers to the specific structure of a network (Burt 1992; Uzzi 1996). An open network structure is usually characterized by so-called non-redundant relationships, in which there is only one way between the network actors. This means that open networks usually generate the transfer of new knowledge. Therefore, the open network is often loosely coupled and exchange between the actors mainly concerns information. A more closed or tighter network, on the other hand, usually improves coordination among the actors in the network since most of the knowledge is available to most counterparts. The flow of new knowledge is then very limited. Closed networks are therefore characterized by tight coupling where social exchange takes place that develops trust and shared norms. Thus, the closed network is a network with a high degree of integration where the actors have strong ties with each other. Strong ties and network closure, in turn, are expected to separate outsiders from insiders in the network (Hilmersson and Jansson 2012a). Thus, it is reasonable to expect that it will be harder to overcome liabilities of outsidership (Johanson and Vahlne 2009) when networks are closed than if the networks are open. Whereas the business network of the firm represents the external environment, research on internationalization has shown that the experience of the firm and its founders will affect the expansion of the firm in business networks (Hilmersson 2013).

\section{Firm international experience}

In internationalization process models, the generation of experiential knowledge is assumed to be a key determinant of internationalization (Johanson and Vahlne 1977; Meyer and Estrin 1997; Dikova and Van Witteloostuijn 2007; Blomstermo et al. 2004; Eriksson et al. 1997). For small and young firms, the experience of the founder is of vital importance in the early face of the internationalization (Madsen and Servais 1997; Oviatt and McDougall 1997). In a recent study, Jones and Casulli (2014) explained how individuals draw on international experience in order to make sense of internationally uncertain, internationally novel, and complex situations that are central to the international expansion of SMEs. By generating international experience, a firm develops knowledge about how to set up foreign operations, how to deal with international competitors, how to adapt its products and services to the needs and wants of international customers, and how to market its products and services abroad. Experiential knowledge is traditionally developed incrementally by the firm; more recent research, however, has underlined that for INVs the prior experience of the founder can shorten the learning process of the firm (Madsen and Servais 1997). It has been argued that experiential knowledge enables firms to make commitments in foreign markets (Johanson and Vahlne 1977) and the more the firm knows about international operations, the less tacit knowledge it needs to generate in each foreign market (Meyer and Estrin 1997). Additionally, Dikova and Van Witteloostuijn (2007) found that international experience reduces the cost and risk of foreign market entry, whereas Hilmersson and Jansson (2012b) showed that it reduces uncertainty in the market entry process. This is in line with Blomstermo et al. (2004), who suggest that firms preoccupied with domestic activities will have difficulties in adapting processes and mental models to the international processes. Thus, international experiences are important, as they are not market-specific. Blomstermo et al. (2004, p. 368) argued that international experiential 
knowledge "can be transferred to and applied in different markets." Similar arguments were forwarded by Eriksson et al. (1997, p. 352), who stated that internationalization experience "is not related to specific country markets, it is a firm-specific experience relevant for all markets." From these arguments, the concept of knowledge translation was developed. It concerns how knowledge generated in one international context is accumulated, modified, and used in another context (Blomstermo and Choi 2003; Choi et al. 2003). It was found that as firms go through a learning process, some properties of knowledge can be translated from one international context to another one (Choi et al. 2003). Thus, internationalization experiential knowledge is seen as a general type of knowledge (e.g., Barkema et al. 1996; Eriksson et al. 1997; Delios and Beamish 1999; Zahra et al. 2000), which is assumed to be translatable to and useful in other markets.

\section{International opportunity development}

Opportunity is a complex concept, which consequently has been defined in various ways in prior research, depending on the purpose, context, level of analysis, and the theoretical assumptions for the SME, the market, and the network (Mainela et al. 2014).

The opportunity concept is largely characterized by the dichotomy between the Kirzner (1973) and Schumpeter (1934) views. Kirzner assumes the opportunity to be the result of the alertness of the entrepreneur who exploits imperfections in prior knowledge distribution. By this view, opportunity is characterized as a reproduction or modification of existing resource combinations (Shane 2012). Schumpeter assumes the opportunity to be the result of the active role of the entrepreneur who introduces innovative combinations of resources and creates market disruptions. By this view, an opportunity is characterized as an innovative resource combination that has novel value in the market (Shane 2012). While the antithesis between Kirznerian and Schumpeterian views on opportunities is common (Shane 2004), both views are complementary, representing different types of opportunities that coexist in the markets (Holcombe 1998; Shane and Venkataraman 2000). Thus, the variation of a firm's entrepreneurial can lead to the development of different types of opportunities in terms of high or low degree of novelty.

Newly developed opportunities can be positioned in the continuum of reproduction of prevailing practices versus the introduction of highly novel practices (Aldrich 1999; Shepherd et al. 2000; Jennings et al. 2009). While opportunity novelty is connected to growth and high value, it can also be hazardous, especially to SMEs. According to Miller and Friesen (1983), extensive risk taking, proactiveness, and strong emphasis on novelty can have detrimental effects on firms under certain circumstances (for example, hostile external environment, threatening periods). Innovative opportunities may include novelty and originality, but at the same time require relatively high risk taking in terms of allocation and utilization of resources (Covin and Slevin 1989; Lumpkin and Dess 2001), which is even more relevant to the scarce availability of SMEs' resources. Thus, the strategic decisions of the firm can vary from more attention to the conservation of the firm's resources to pursuing more novel and risk-demanding opportunities. 
Prior research on international entrepreneurship shows the central role of opportunity but lacks in-depth analysis of the concept and the consequences for the SME. Moreover, entering new markets in the context of creating new exchanges is largely neglected in the entrepreneurship literature (Ellis 2011). We use an exchange-based definition of the concept of opportunity, as exchange is the essential element in value creation. Furthermore, overcoming barriers for the flow of information and resources between distant exchange partners requires an act of entrepreneurship (Ellis 2011).

Searching and negotiating an exchange with a new customer in a new market includes all the elements of entrepreneurial discovery, evaluation, and exploitation (Shane and Venkataraman 2000). In this context, the opportunity is seen as the potential to exchange goods and services among partners in different markets resulting in new means-ends relationships (Kirzner 1997). We focus on the opportunities, which were exploited and formed new international exchange. Entering a new market is considered an act of innovation for both domestic and international SMEs according to the international business literature (Andersen 1993; Bilkey and Tesar 1977; Cavusgil 1980; Czinkota 1982; Reid 1981). An exchange can be characterized as innovative only if it has not taken place before. It is furthermore important to distinguish between two types of exchanges between partners in an international context: exchanges between new entry partners and exchanges between new partners in the same market. Exchanges with new partners in the same market are not entrepreneurial acts since such exchanges have happened before in that context. These exchanges can be characterized as domestic opportunities and are not relevant to international business research. In contrast, an unprecedented exchange in a new market constitutes an international business opportunity. We thus define international opportunity as the prospect to conduct exchange with new partners in new foreign markets (Ellis 2011). Additionally, we seek to examine the degree of novelty of such opportunities.

\section{Research model}

The theory developed to answer the research question centers on four core constructs developed from literature: network characteristics, international experience, opportunity scouting, and opportunity novelty. It is a synthesis of established theories and constructs relevant to examining how SMEs develop international opportunities in international business networks. As visualized in Fig. 1, we have

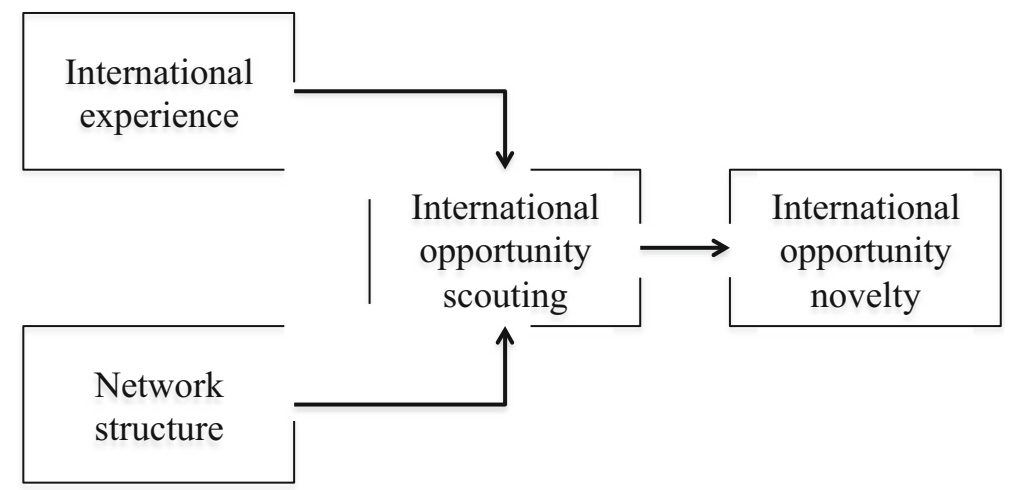

Fig. 1 Research model 
theoretically derived that the international experiences of the firm and the network structure are likely to influence the international opportunity scouting behavior. The scouting behavior, in turn, is likely to influence the degree of novelty of the opportunity developed (Table 1).

\section{Method}

In this paper, we set out to develop theoretically and empirically based propositions. These propositions are founded on a study of relatively few firms since we need inside and detailed qualitative data. Still, the firms cannot be too few, as it would jeopardize the variation needed to develop propositions. To handle this dilemma, we take an abductive approach and perform a multiple case study enabling the development of a well-structured theory with strong empirical support. Along the lines suggested by Dubois and Gadde (2002), we therefore have let the theoretical framework evolve in parallel with our empirical fieldwork and the case analysis. Our approach is beneficial in comparison to an inductive logic as the theory provides us with structure. Compared to the deductive approach, our qualitative data gives an in-depth understanding of the causality, which is of central importance to developing the propositions. At this stage, however, the theory generated cannot be validated and tested, which remains for later research. Instead, the external validity of the study should be evaluated through analytical generalization, where the findings are related to a broader theory (Yin 2009). This requires an acceptable internal validity, where the aim is to establish proper relationships between the constructs - to establish the foundation for the propositions (Yin 2009) (Table 2).

We found a case study as the preferred empirical approach as it allowed us to make use of various empirical data sources (Merriam 1998; Yin 2009). Our key data source was recorded interviews, but we also used other documentation and secondary data sources. The case studies were performed from October 2013 until March 2014. We applied a longitudinal and retrospective design for our case studies (Tripsas and Gavetti 2000). For the interviews, we developed a semi-structured questionnaire that covered the most central aspects of the international opportunity development process as well as the background information on the firms. The questions were in some cases adapted to the individual firm. The semi-structured questionnaire was combined with a structured questionnaire (see Table 3 where the shadowed headings represent the themes for interviews and the structured questions are presented) on the key constructs in order to increase the quality of our analysis. By doing so, we were able to complement our interpretations of the interview with the informants' rating of the firm on the most central constructs.

To reach an appropriate match between the theoretical constructs and the empirical reality, a purposeful sampling of the firms was applied. The cases were chosen based on the ability to provide rich descriptions. Apart from this criterion, we decided to study firms that fall within the EU definition of SMEs that had developed international opportunities within the last 7 years. At each firm, we interviewed the CEO and/or the managing director. A preliminary interview of about 20 min was made over the 


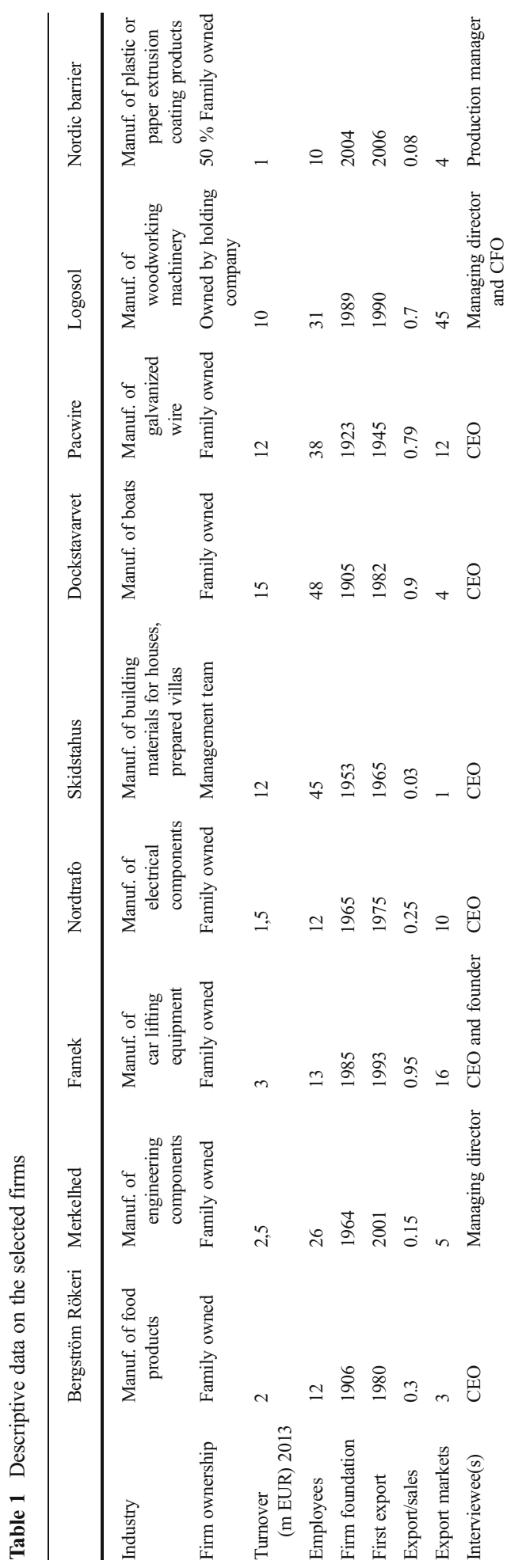




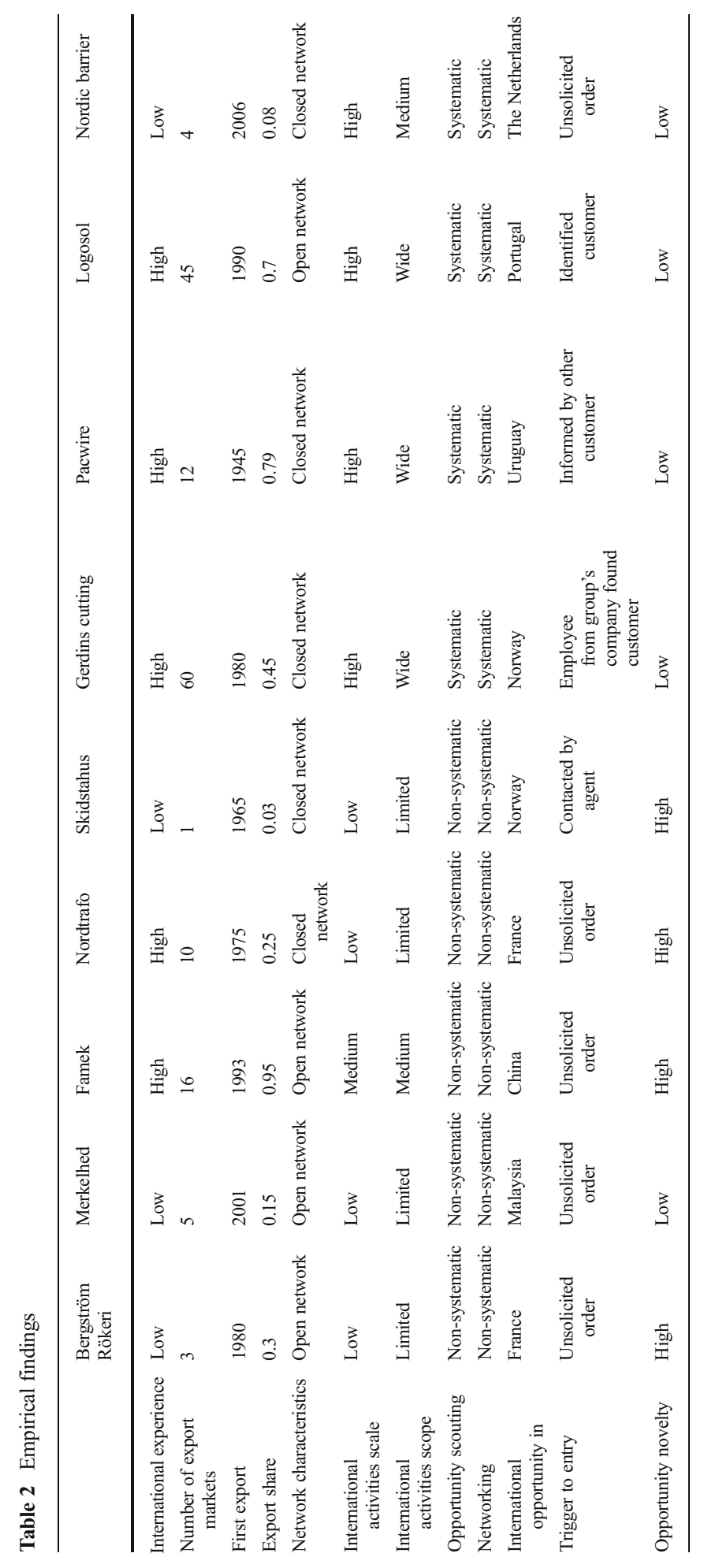


phone and main interviews on-site lasted between 1 and $2 \mathrm{~h}$ with an average of one and a half hour.

To safeguard internal validity, we first developed a theory based on previous research on networks, international opportunities, and firm internationalization. Throughout the research process, the theory was continuously assessed against the empirical world, patterns being matched and alternative explanations addressed. To uphold the construct validity, critical incidents or changes were defined. The theory was continuously confronted with the empirical data at the same time the empirical support of the theory was being assessed. Second, we decided to structure our analysis of the data; we first performed an intra-case analysis, which served the purpose of evaluating each firm in relation to the theoretical conceptualization of our research. For this purpose, we abstracted the information on each case to establish a match between the theory and the empirical reality. This step of the analysis was taken to safeguard the internal and the construct validity in this research. For our second step of the analysis, we performed a cross-case analysis. This cross-case analysis served the purpose of developing the propositions. At this point, the variation on the theoretical constructs was used as ground for the theoretically based and empirically generated propositions developed in this study. By doing so, we enable future research to test the relationship between the constructs in this research on a broader sample of firms.

In the empirical section, we present in-depth data on two of the cases. The remaining seven cases are presented in Tables 2, where we summarize our findings from the case studies. The empirical section is followed by our cross-case analysis where propositions are generated.

\section{Empirical data}

\section{Bergström Rökeri}

Bergström Rökeri is a third generation, family-owned business in the food industry. Founded in 1905 in Själevad, a small town in the northern parts of Sweden, the firm specializes in smoking various kinds of meat. Its product assortment includes reindeer, elk, deer, lamb, and pork. After a century in the northern parts of Sweden, Bergströms Rökeri started to export in the 1980s. Its first export addressed the Norwegian market, which was followed by Denmark and Finland. A continuous growth in exports to the Nordic markets was maintained, and in $2012,30 \%$ of the sales were from exports. At that point of time, there were 12 employees and the firm supplied three export markets. Consequently, Bergströms Rökeri had a limited experience of supplying foreign customers and marketing their products abroad. Even though 30\% was exported, the firm had not had any sales outside the Nordic countries during their first 100 years of existence. The structure of the firm's business network is relatively open, and the information within the business network does not flow easily. The firm does not actively search for information and contacts in order to find opportunities for international expansion. They consider such activities resource demanding and beyond the focus of the firm. Few of the employees travel abroad frequently. There are no routines for how to follow newspapers, business press, magazines, or trade publications regularly to acquire new information about international markets. Consequently, Bergströms 
Rökeri does not actively search for foreign customers, and instead their international ventures have been the result of potential customers or agents contacting Bergströms Rökeri. The CEO puts it:

You must have a lot of money to put in to search for new exports even for trade fairs. We started to visit trade fairs in Germany and France but not with our own both. We are visitors there and we wonder around if luck strikes again and we meet someone important like the agent in Denmark. He found us at a trade fair we were visiting in Germany and he became our Danish agent from 1988. It was a lucky meeting.

An example of the passiveness and non-systematic international opportunity scouting was Bergströms Rökeri's attempt to enter the Greek market. The firm consulted the network organization of Business-Sweden in Athens. Through Business-Sweden, a potential customer was found. Very positive feedback on the sample products was received and Bergströms was provided a lot of information about the Greek market. Still, with the support of knowledge and contacts, in parallel to the positive feedback from promising potential customers in Greece, the firm did not manage to develop this international opportunity into any sales. The CEO says:

Look at this big pile of papers. They are about the Greek market. We received a lot of information from Dimitris Oraiopoulos, the local contact of BusinessSweden. He found us customers that would be interested in our products and we sent them samples, which they loved. I went to Greece and had many meetings with Dimitris. But eventually we did not sell to them. You need to be present there, to have someone there working full-time for you and to know the language. Unfortunately, we did not make any sales in Greece.

Despite the inactive and non-systematic approach to export markets, Bergströms Rökeri accidentally entered France in 2009. The entry is described as an unplanned but very positive event. The CEO says:

We started to sell in France because we were really lucky. We did not know that IKEA, our local customer in Sweden, was selling our products in France for a short while. After they stopped selling our products to the IKEA food stores, we received a call from the French customer. From this phone call we learnt that these customers were buying whole cartons of our products from IKEA in France. They asked for permission to continue to purchase our products, they asked if we could send them the products directly. If IKEA had continued to sell our products, we would never learn that we have a French customer. Today, this is an important customer, they buy the top of our product line. This is the story of our exports. Lucky shooting here and there.

The firm considers their entry into the French market as unique. They were really lucky to find the French customer that contributed a lot of value. They continue to be their sole customer in France. The firm did not have any knowledge about the French 
customer in advance and describes the development of this international opportunity as a product of pure chance, uniqueness, and novelty for the firm. It was an accident, and all Bergströms had to do was to deliver the products to France.

\section{Gerdins Cutting Technology AB}

Gerdins Cutting Technology was established in late 1980s in Mjällom, a small town in Northern Sweden. They specialize in manufacturing cable and metal components. The firm has 60 employees with a turnover of three million euros. Since 2010, they have had a stable export share of $45 \%$ of total sales. Right from its inception, the firm was actively exporting to 10 countries including Scandinavia, Germany, and other European countries. The remote and small town of Mjällom did not hinder the firm's internationalization. Gerdins experienced a gradual growth in export markets. Around two new countries were entered per year during the first 20 years of the firm's history. In the year of 2000, 60 countries were exported to. The export reach of Gerdins' Cutting Technology then included distant markets such as Bangladesh, South Africa, and countries in South and North America. They have established a well-developed knowledge of supplying international customers and international experience in marketing and selling their products abroad. Their business network is relatively closed, as the CEO puts it:

In our market, everyone knows everyone. We have so many international contacts that it is very rare that I meet situations when I cannot access the information I need, this is the case also regarding very distant markets. I always find someone in our extensive network of people around the world to provide me with the information I look for.

Part of the strategic plan for the company is to actively and systematically search for new international business opportunities. They carefully plan before any action is taken, and they specify in advance what information they look for and how to obtain it. The firm spends substantial time and resources to find new international business opportunities mainly by utilizing their international business network. They regularly participate in international trade shows, interact with business acquaintances, and put effort into reaching and developing relationships with the right people abroad. The CEO puts it:

We have such an extensive network of our people around the world. Look at the map behind you. See all these red pins? This is where we have contacts. It's everywhere. Whenever we need some info we contact our people regardless how distant they are located. This is mainly my job: To be in constant contact with our people everywhere.

The most successful way of finding international opportunities was formulated as a specific networking process. The company utilized its business network in a specific way to gain more information about potential customers: The CEO describes the strategy: 
We have a way of networking that proved really successful so far. We contact companies, which have the same market focus and similar customers with us, but they are selling complementing products so they are not competitors. We try to find companies selling complementary products to the same customers which can be our own potential customers. We contact them and we create a mutual beneficial relationship since we have business contacts and potential customers for both of us at the same time we can both sell different products to the same customers not competing to each other. This is what I am trying to do, find all these complementary firms within our industry.

Consistent with the above, the firm found a customer in Norway. This happened in 2009. Prior to this, it had no sales in Norway. One of the employees of a sister company within the Gerdins industrial group, which was located in Norway, found a potential new customer for Gerdins Cutting Technology. This employee approached the potential customer and at the same time informed Heiko Schindelmeiser, CEO of Gerdins Cutting Technology, who followed the suggestion and directly contacted the potential customer. Entering Norway was not perceived as something unique or novel for the firm. Instead, the entry in Norway followed the firm's prior strategy and international plans. It was a result of their intention to expand internationally, and Norway was a market aimed for. The CEO says:

In Norway we had people we trust. But still, we as a company did not sell any components to Norway. This had to change and we actively searched for the right people there to help us. This is why we approached our sister company. They had their own sales office located there so they should have the information and contacts we need. And it proved to be a right decision since the employee of our sister company was part of making the deal.

\section{Generation of propositions}

\section{International experience and international opportunity scouting}

While some firms systematically identify and act upon fragments of information, resulting in the development of new international opportunities, other firms are more inactive and non-systematic. Their internationalization has even been described as accidental (Hennart 2014). Prior studies indicate the importance of experiential knowledge in explaining this heterogeneous behavior. Firms and individuals with relevant prior experience are able to identify opportunities while entrepreneurs without relevant knowledge are incapable of recognizing them (Venkataraman 1997; Shane and Venkataraman 2000). Previous research has also shown that relevant prior experience reduces the perceived uncertainty and risk of potential market entries (Hilmersson 2013). The influence of experiential knowledge in risk perception is well established in the internationalization research (Bilkey and Tesar 1977; Johanson and Wiedersheim-Paul 1975) and in turn influences the confidence, propensity, and international orientation of the firm in relation to entering new markets. It has also been 
shown that lack of prior experience sometimes results in overestimation of risk and resources needed to exploit international opportunities and enter new markets. Knowledge acquired in the past affects the way entrepreneurs understand, analyze, monitor, and apply newly acquired information (Roberts 1991). Experience from past activities has an effect on the future behavior of the firm (Pedersen and Petersen 1998) and the ways a firm searches and acquires information for potential international opportunities. Evidently, the stock of international experience of a firm is expected to shape the future international behavior and will affect its international opportunity scouting activities (Fig. 2).

Our data reveals a pattern on the relation between prior international experience and international opportunity scouting activities. On the one hand, the group of firms that is internationally inexperienced had no intention of engaging in any systematic activities. These SMEs (Bergströms Rökeri, Merkelhed, and Skidstahus) were relatively passive and non-systematic. Instead of aiming to expand internationally, they perceived internationalization as a costly and risky process. Instead of actively undertaking any systematic activities to expand in the international market, these firms have acted on unsolicited orders from their customers. Their customers, in turn, were willing to do all necessary arrangements and did not expect any product customizations. International customers were therefore treated as the domestic ones. Thus, the internationally inexperienced SMEs did not actively engage in any systematic scouting activities.

On the other hand, five out of nine case companies had prior experience with foreign markets, international customers, and suppliers and had knowledge about the international business context. These experienced SMEs systematically and actively searched for information and ways to enter new markets. Gerdins Cutting Technology, Pacwire, and Logosol worked in an international context before and had acquired international knowledge from previous market entries. For example, Gerdins Cutting Technology had a sister company already doing business in Norway, a market in which they were not doing business before. In this case, Gerdins Cutting replicated the scouting activities they have engaged in the past market entries. Dedicating substantial time,

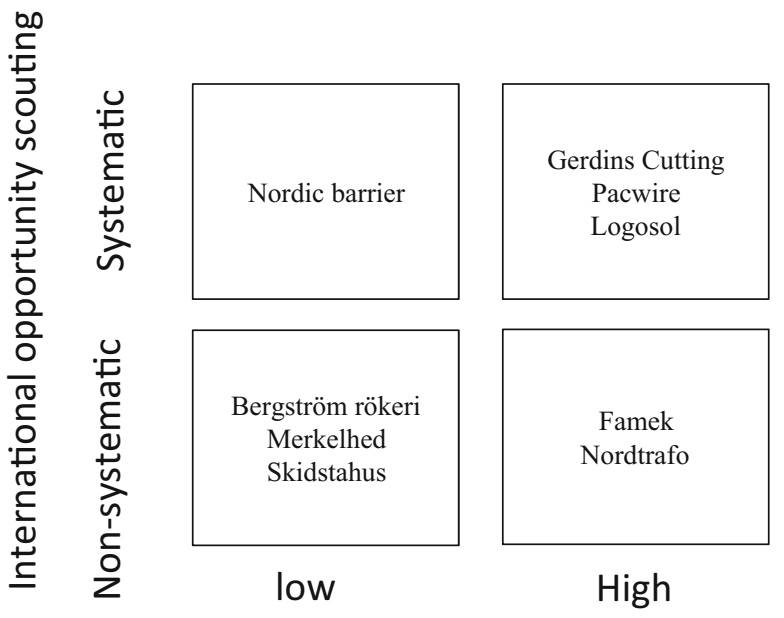

International experience

Fig. 2 International opportunity scouting and international experience 
the CEO gathered information about the Norwegian customer and its suppliers. He discovered that a sister company from the Gerdins group was already a supplier for the Norwegian customer and made all necessary contacts in order to contact the potential customer through the sister company. This process, which was repeated for entering other markets in the past, resulted in entering in the Norwegian market. In contrast, despite the fact that Famek and Nordtrafo had well-developed international experience, they were hampered to expand internationally by their production capacity. Therefore, they did not engage in any systematic opportunity scouting. Moreover, despite the fact that Nordic Barrier had restricted international experience, the recent management change with a more internationally experienced CEO affected the more systematic opportunity scouting behavior of the firm.

This pattern leads us to establish the relation between international experience and the international opportunity scouting behavior of the firm. Firms that possess international experiences are not likely to overestimate risks and uncertainties regarding international operations. Instead, they are able to transfer and transform their previous experiences and leverage them for new opportunity development. Consequently, the empirical pattern revealed in our study finds support for previous studies (Dikova and Van Witteloostuijn 2007; Blomstermo et al. 2004; Eriksson et al. 1997; Hilmersson and Jansson 2012a, b). International experiences are useful for reducing the costs, risks, and uncertainties in the internationalization process. Therefore, we propose that:

P1. The greater the international experience of the SME, the more systematically the SME will scout for international opportunities

\section{Network structure and international opportunity scouting}

Firms rely on external knowledge that can be accessed only through network relationships (Johanson and Mattsson 1988) since the knowledge exchanged within networks is difficult to codify (Powel 1990). The value of knowledge in networks increases when firms enter new markets (Sharma and Blomstermo 2003). Internationalization decisions are influenced by interactions with others, which is confirmed by numerous past studies (Johanson and Mattsson 1988; Ellis and Pecotich 2001; Wilkinson and Young 2005; Chetty and Blankenburg-Holm 2000). Social interactions are often considered as the most valuable resource of the firm from which the firm taps knowledge and information to serve its objectives. Apart from reacting to opportunities that may arise in the business environment, firms also seek to actively develop international opportunities (Autio 2005). A number of studies indicate unsolicited orders to trigger reactive opportunity creation (Ellis and Pecotich 2001; Crick and Spence 2005). On the other hand, internationally experienced firms tend to deliberately search for international opportunities in a more systematic behavior.

The network structure in which the firm is embedded is likely to influence the opportunity scouting behavior. Closed networks are characterized by strong and longterm relationships among the network nodes and stability. Everyone knows everyone and novel knowledge is unlikely to be transferred among network nodes. In contrast, open networks are characterized by dynamism and instability, which can lead SMEs to overestimate perceived risk. Thus, network structure is likely to affect the risk-averted 
SMEs to invest resources in systematic and active scouting for international opportunities (Fig. 3).

Our data reveals that SMEs embedded in more open networks are more inactive and non-systematic in the opportunity-scouting phase. All cases (Bergströms Rökeri, Merkelhed, and Famek) except one (Logosol) were embedded in open business networks, showed a more non-systematic attitude towards new international opportunities, and in some cases this passiveness was explicitly stated as their internationalization strategy. These firms all underlined that they did not possess the resources required to expand internationally. They were unable to finance any search for new contacts or information. Instead, these SMEs were relatively satisfied with the surprise of unsolicited international orders focusing on the minimization of cost and risk and less on the potential benefits of entering new markets. These firms also demonstrated a lower willingness and ability to customize their products and their organization to different markets. In other words, the SMEs that are embedded in a more open and unstable network tend to satisfy the customers that are similar to their home market, acting on unsolicited orders as a strategy to extend their market reach.

On the other hand, SMEs (Gerdins Cutting Technology, Pacwire, and Nordic Barrier) embedded in closed networks demonstrate a more systematic and active opportunity scouting behavior. This can be explained by the reduced risk perception that is influenced by the stability, trust, and long-term nature of the relationships among members of relatively closed networks. Nordtrafo, operating in a closed business network, is still not engaged in any systematic scouting behavior because of its limited production capacity. Skidstahus has a barrier to export as some of their products have high transportation costs. Taken together, these findings indicate that the network structure influences the SMEs' international opportunity scouting behavior. SMEs demonstrate more systematic opportunity scouting in relatively closed and stable networks. SMEs embedded in open networks, on the other hand, are less systematic and more passive in the international opportunity scouting. Therefore, we formulate our second proposition:

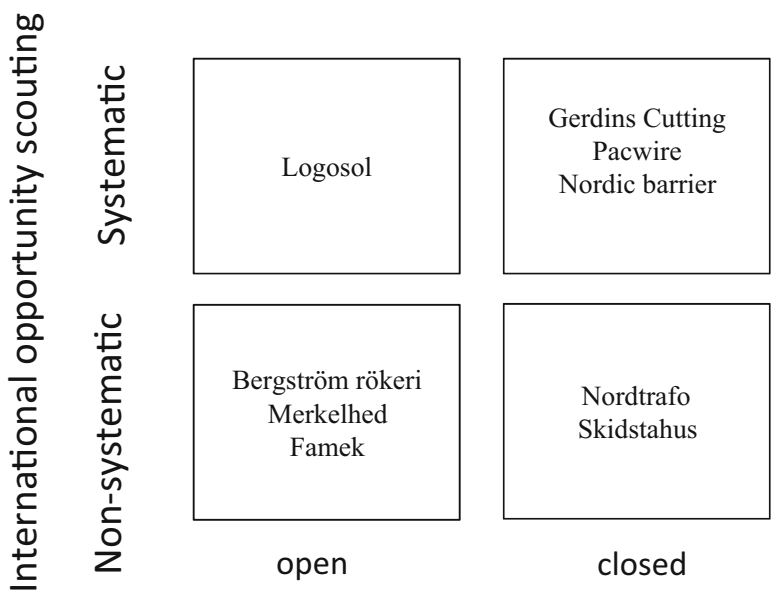

Networkstructure

Fig. 3 International opportunity scouting and network structure 
P2. The more closed the network the SME is embedded in, the more systematically the SME will scout for international opportunities.

\section{International opportunity scouting and opportunity novelty}

Firms that are successful in their growth efforts are likely to repeat the same actions and strategies over time. Experiences of successful actions are therefore valuable for the growth-aspiring SME. Previous research has shown that repetitive behavior, however, might lead to learning myopia (Levinthal and March 1993; Tsang 2002) and the "lockin" phenomenon (Sydow et al. 2009). In cases where a particular outcome reproduction is the result of one particular predominant action pattern, the firm risks to lose its capability to adopt better alternatives and might become path dependent. For the development of future opportunities, this may result in the development of opportunities with similar attributes and low degrees of novelty. The type and characteristics of future and potential opportunities to be developed would be dependent on the historical path of developed opportunities of the past. Thus, experiential knowledge can also lead to a reduced innovativeness of the firm (Levitt and March 1988) (Fig. 4).

Our data indicates that firms systematically scouting for international opportunities developed opportunities with relatively low degrees of novelty. A striking indication of the phenomenon is the difference between Skidstahus and Gerdins Cutting Technology. Both of them entered Norway. Skidstahus did not systematically scout for opportunities in Norway, nor did it seek for information about Norwegian customers. Gerdins Cutting Technology, in contrast, actively and systematically searched for information and new relationships in the Norwegian market. Skidstahus described the entry into Norway as highly novel and with a lot of unique characteristics. Gerdins Cutting Technology, on the other hand, described it as an opportunity with a low degree of novelty.

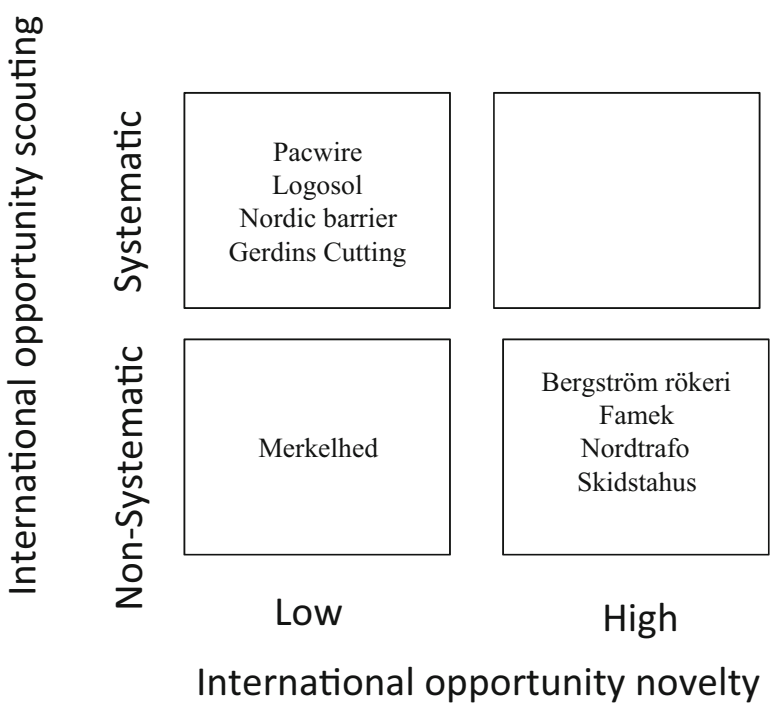

Fig. 4 International opportunity scouting and international opportunity novelty 
Our findings indicate that SMEs identify opportunities that are similar to what they have experienced before. SMEs scouting for opportunities similar to their past experiences will develop similar and not novel opportunities in foreign markets. Scouting for potential international opportunities can lead to a rigid pattern of opportunity development actions resulting in an increased number, but similar opportunities with decreased novelty. Therefore we propose that:

P3. The more systematically the SME scouts for international opportunities, the lower the novelty of the opportunities identified by the SME.

\section{Conclusions, implications, and further research}

\section{Determinants of the international opportunity scouting strategy}

Prior to this research, international opportunities have come to occupy a central position in our understanding of the internationalization of firms. It has been shown that the ability of the firm to recognize, discover, or create international business opportunities regulates the internationalization of the firm. Existing research have identified internal as well as external determinants of the international opportunity development process. Yet, we have claimed that current research has been static in its nature, and few studies have addressed the opportunity development strategies of firms. Instead, the lion's share of the received literature has identified the prerequisites under which such opportunities are developed. Thus, along the arguments of Chandra et al. (2009) and Ellis (2011), we have argued that there is a shortcoming in the literature on the underlying mechanism of opportunity development.

Consequently, our paper has added knowledge to the role of internal determinants on the international opportunity development mechanism. Along the lines presented by Johanson and Vahlne (2009) and Schweizer et al. (2010), we have shown that the international experience of the firm is an important determinant of the international opportunity development. We have added to this field of research by showing that the international experience of the firm affects how systematically and actively the SME will scout for international opportunities. The more international experience the firm has, the more likely it will actively and systematically scout for new international opportunities.

As for the external determinants, our findings add knowledge to the research presented by Kontinen and Ojala (2011) as well as Chandra et al. (2009), who showed that the network ties of the firm influences the opportunity recognition process. Our paper has added knowledge to these findings as it has shown that the network structure of the firm is an important determinant of opportunity scouting. Our findings revealed that, in relatively closed business networks, firms are systematically scouting for new opportunities whereas in open networks, firms tend to have a more passive and nonsystematic approach to the opportunity development process.

\section{Outcomes of the opportunity scouting strategy}

Apart from identifying the determinants of the international opportunity development mechanism, our article also seeks to develop knowledge regarding the outcomes of the 
opportunity scouting strategies of firms. In this study, we have developed a model that examines the degree of novelty of international opportunities. Our argument is that prior research in internationalization and on international opportunities has treated international opportunities homogenously. We argue that this is a shortcoming in the literature as international opportunities come with heterogeneous outcomes and are of heterogeneous novelty to the firm.

In this paper, we have shown that firms systematically scouting for international opportunities will develop opportunities with low degrees of novelty. Instead of identifying novel opportunities, these firms are more likely to reproduce prevailing practices. Thus, by doing more of the same, the firm reduces its innovativeness, but also the degree of risk taken. Consequently, we have shown that the opportunity developed by the firm is dependent on the previous behavior of the firm. We argue that these findings show that the systematic internationalization process of the firm is path dependent.

Accordingly, our paper has contributed to an increased understanding of the underlying determinants of the international opportunity process. We have shown that the opportunity scouting of the firm determines the type of opportunities developed. Our proposed model shows that the greater the international experience of the SME, the more systematically the SME will scout for international opportunities. The more closed the network the SME is embedded in, the more systematically the SME will scout for international opportunities. The more systematically the SME scouts for international opportunities, the lower the novelty of the opportunities developed by the SME.

Furthermore, we argue that the concept of opportunity novelty is important for the future advancement of knowledge in the field of international entrepreneurship and internationalization research. In the internationalization process literature (Johanson and Vahlne 1977, 2009), internationalization is described as an incremental process dependent on the experience of the firm. Viewing this theory through the international opportunity lens, two implicit assumptions are central. First, firms are expected to develop opportunities that are close to the previous experiences of the firm. Second, firms are assumed to develop opportunities from their ongoing operations. As a consequence, opportunities that are very different from the previous experiences of the firm are assumed to be overlooked by managers, or simply avoided as they are beyond the accepted risk level (Figueira-de-Lemos et al. 2011). Thus, the traditional internationalization research has been criticized for being path dependent. Consequently, we argue that the internationalization research implicitly assumes that international opportunities that are developed have a low degree of novelty.

More recent observations have challenged these ideas. We have articles showing that firms are leapfrogging steps in the internationalization process. Thus, a parallel stream of literature observes that the process is not always incremental, linear, and gradual; instead, firms are leapfrogging in both small and big steps (Hedlund and Kverneland 1984). Thus, firms act on opportunities with greater novelty. We argue that the concept of opportunity novelty may be an important and so far overlooked factor explaining the heterogeneity of behavior among firms. Firms that are able to develop novel opportunities are also able to change their path of internationalization. By developing abilities to capture and develop novel opportunities, the instrumentality and the path dependency of the internationalization process can be broken. Thus, instead of searching for more of what is already known by the firm, new experiences can be developed and new 
potentials for growth can be acted on. Along with previous research in the field, we argue that this is an act of entrepreneurship. We argue that, in order to do so, the managers of the firm need to develop internationalization capabilities in order to reduce uncertainties and risks with international operations, but to develop novel opportunities, the firm also needs to develop entrepreneurial capabilities to enable steps outside the entered path. By doing so, the firm can act on novel opportunities leading to innovative growth, leapfrogs in the internationalization process, and an accelerated speed of the internationalization process.

\section{Managerial implications}

Our paper has suggested new insights on the determinants and consequences of the international opportunity scouting strategy of the firm. For managers of internationalizing firms, we argue that the pattern revealed on the consequences of opportunity scouting strategy should be of interest. Ultimately, we have shown that novel opportunities are the outcome of entrepreneurial behavior in the international market. The first managerial implication from these insights is that managers developing strategies based on previous experiences may miss out on novel opportunities. There is a risk that experience-guided firms miss out on novel opportunities. Instead of developing such opportunities, these firms take risks to merely reproduce existing practices, thus hampering the innovativeness of the firm. The second managerial implication from our study is that systematic opportunity scouting behavior is difficult in open business networks. If there are many general and weak ties between the actors of the network, managers need to develop more flexible opportunity scouting strategies. The third managerial implication is that international experience will enable a systematic scouting behavior. But managers of internationally experienced firms need to revitalize their resource base and their strategies in order to avoid suffering from learning myopia.

\section{Limitations and suggestions for further research}

In this paper, we have developed theoretically and empirically based propositions. These propositions can be generalized to a broader theory, but not statistically. Future research should address this shortcoming by developing the propositions into hypotheses tested on a larger sample of firms. It would be valuable if such endeavors would be undertaken on international samples, compensating for potential home market biases, as well as other industries compensating for the potential industry biases of our research. Another potential limitation of our paper is that we have selected the cases based on opportunities developed. This means that we can reach conclusions regarding firms that have developed opportunities. As most other research projects in international entrepreneurship, we lack information regarding failures or missed opportunities. This is an important shortcoming when evaluating proposition number three. It should be noted here that we do not suggest that firms being non-systematic in the scouting process will develop novel opportunities. There are many passive and non-systematic firms that do not develop any international opportunities. Still, we argue that the more systematic the firm is, and the more actively the firm seeks to exploit its internationalization capabilities, the lower the degree of novelty of the opportunity developed. 
Hopefully, future research will compensate for this shortcoming by studying more failed international attempts and to evaluate their determinants and outcomes. Another potential shortcoming that can be compensated for in future research relates to the level of analysis. In this paper, we have focused on the business network of the firm and its influence on the opportunity scouting behavior of the firm. Research on entrepreneurial networks (e.g., Johannisson 1996) and the social capital of the entrepreneur (Houston and Gassenheimer 1987) has underlined the importance of the social aspects in the expansion process of SMEs, which future research could address and develop and evaluate the propositions presented in this paper.

\section{Appendix}

\section{Table 3}

International experience

$1=$ Completely disagree, $7=$ Completely agree

We have well-developed experience of...

149 Supplying foreign customers

$\begin{array}{llllllll}1 & 2 & 3 & 4 & 5 & 6 & 7\end{array}$

150 Adapting our products and services to meet the needs and wants of foreign customers

151 Adapting our organization to meet the needs and wants of foreign customers Marketing and sales of our products and services abroad

Network

$1=$ Completely disagree, $7=$ Completely agree

In our market, companies usually have knowledge about their suppliers' suppliers'...

153 Products and technology

154 Markets and customers

In our market, companies usually have knowledge about their customers' customers'...

155 Products and technology

156 Markets and customers

157 In our market, competitors often know each other quite well

158 It is difficult to keep commercial secrets in our market

159 Information flows easily between companies in our market

$\begin{array}{lllllll}1 & 2 & 3 & 4 & 5 & 6 & 7\end{array}$

160 We are often reached by the same news from more than one company in our market

161 In our market, everyone knows everyone

In our market...

162 The business between companies is dependent on the social relations between people in the companies

165 It is necessary to have frequent contacts with the customers

$\begin{array}{lllllll}1 & 2 & 3 & 4 & 5 & 6 & 7\end{array}$

166 Companies often solve problems together

167 The supplier's and the customer's operations are often integrated

$\begin{array}{lllllll}1 & 2 & 3 & 4 & 5 & 6 & 7\end{array}$

168 People from different firms tend to meet outside work

$\begin{array}{lllllll}1 & 2 & 3 & 4 & 5 & 6 & 7\end{array}$

169 Trust between people is important for the business the companies do 
Table 3 (continued)

The relations between the companies are characterized by:

163 Integrated delivery systems

$\begin{array}{lllllll}1 & 2 & 3 & 4 & 5 & 6 & 7\end{array}$

164 Modification of production in order to fit customers

Opportunity scouting

$1=$ Completely disagree, $7=$ Completely agree

In our firm...

217 Dedicate substantial time and resources to finding new international business $\quad \begin{array}{lllllll}1 & 2 & 3 & 4 & 5 & 6 & 7\end{array}$ ideas.

218 Have firm incentives encouraging international expansion ideas

$\begin{array}{lllllll}1 & 2 & 3 & 4 & 5 & 6 & 7\end{array}$

219 Carefully follow newspapers, magazines, or trade publications regularly to

$\begin{array}{lllllll}1 & 2 & 3 & 4 & 5 & 6 & 7\end{array}$ acquire new information

220 Frequently travel abroad

221 Always keep an eye out for new international business ideas when looking for $\begin{array}{lllllll}1 & 2 & 3 & 4 & 5 & 6 & 7\end{array}$ information

222 Actively search for foreign customers

223 Continuously search for information about international markets

224 Improvise solutions to problems

$\begin{array}{lllllll}1 & 2 & 3 & 4 & 5 & 6 & 7\end{array}$

225 Often deviate from plans in order to take advantage of opportunities in the moment

Opportunity scouting-networking

To expand internationally we...

227 Put effort to reach and develop relationships with the right people abroad

228 Interact with business acquaintances to access new information

229 Interact with personal friends and acquaintances to access new information

230 Regularly participate in international trade shows

231 Follow customers expanding internationally

232 Make use of the support from network organizations

Novelty

$1=$ Completely disagree, $7=$ Completely agree

We ask you to consider the following suggestions regarding your entry in X...

367 Entering into the $\mathrm{X}$ market can be characterized as unique (or pioneering) for us $\begin{array}{lllllll}1 & 2 & 3 & 4 & 5 & 6 & 7\end{array}$

368 We entered the X market by following our firm's prior strategy

370 In advance, we did not have any knowledge about that we would find this customer

371 We were really lucky finding this customer

372 Finding this customer has been important for our further expansion in $\mathrm{X}$

373 Finding this customer could be characterized as unique for us

\section{References}

Agndal H, Chetty S (2007) The impact of relationships on changes in internationalisation strategies of SMEs. Eur J Mark 41(11/12):1449-1474

Aldrich H (1999) Organizations evolving. Sage, London

Andersen O (1993) On the internationalization process of firms: a critical analysis. J Int Bus Stud 24(1):209231 
Autio E (2005) Creative tension: the significance of Ben Oviatt's and Patricia McDougall's Article "Toward a Theory of International New Ventures". J Int Bus Stud 36(1):9-19

Barkema HG, Bell JH, Pennings JME (1996) Foreign entry, cultural barriers and learning. Strateg Manag J 17 : 151-166

Bilkey WJ, Tesar G (1977) The export behavior of smaller-sized Wisconsin manufacturing firms. J Int Bus Stud 8(1):93-98

Blomstermo A, Choi S (2003) Product complexity and knowledge translation in the internationalisation process of firms: an integrative model. In: Blomstermo A, Sharma D (eds) Learning in the internationalisation process of firms. Edward Elgar, Cheltenham, pp 175-190

Blomstermo A, Eriksson K, Lindstrand A, Sharma DD (2004) The perceived usefulness of network experiential knowledge in the internationalizing firm. J Int Manag 10(3):355-373

Burt R (1992) Structural holes: the social structure of competition. Harvard University Press, Cambridge

Butler JE, Doktor R, Lins FA (2010) Linking international entrepreneurship to uncertainty, opportunity discovery, and cognition. J Int Entrep 8(2):121-134

Cavusgil ST (1980) On the internationalization process of firms. Eur Res 8(6):273-281

Chandra Y, Styles C, Wilkinson I (2009) The recognition of first time international entrepreneurial opportunities: evidence from firms in knowledge-based industries. Int Mark Rev 26(1):30-61

Chetty S, Blankenburg-Holm D (2000) Internationalisation of small to medium-sized manufacturing firms: a network approach. Int Bus Rev 9(1):77-93

Choi SG, Eriksson K, Lee JH (2003) Knowledge translation in the internationalization process of the Hyundai motor company. Learning in the internationalisation process of firms. Edward Elgar, Cheltenham

Covin JG, Slevin DP (1989) Strategic management of small firms in hostile and benign environments. Strateg Manag J 10(1):75-87

Crick D, Spence M (2005) The internationalisation of "High Performing" UK High-Tech SMEs: a study of planned and unplanned strategies. Int Bus Rev 14(2):167-185

Czinkota MR (1982) Export development strategies: US promotion policy. Praeger, New York

Delios A, Beamish PW (1999) Geographic scope, product diversification, and the corporate performance of Japanese firms. Strateg Manag J 20(8):711-727

Dikova D, Van Witteloostuijn A (2007) Foreign direct investment mode choice: entry and establishment modes in transition economies. J Int Bus Stud 38(6):1013-1033

Dubois A, Gadde LE (2002) Systematic combining: an abductive approach to case research. J Bus Res 55(7): 553-560

Ellis PD (2011) Social ties and international entrepreneurship: opportunities and constraints affecting firm internationalization. J Int Bus Stud 42(1):99-127

Ellis P, Pecotich A (2001) Social factors influencing export initiation in small and medium-sized enterprises. J Mark Res 38(1):119-130

Eriksson K, Johanson J, Majkgard A, Sharma DD (1997) Experiential knowledge and cost in the internationalization process. J Int Bus Stud 28:337-360

Figueira-de-Lemos F, Johanson J, Vahlne JE (2011) Risk management in the internationalization process of the firm: a note on the Uppsala Model. J World Bus 46(2):143-153

Hedlund G, Kverneland K (1984) Are establishment and growth patterns for foreign markets changing. The case of Swedish investment in Japan. Institute of International Business, Stockholm School of Economics, Stockholm

Hennart JF (2014) The accidental internationalists: a theory of born globals. Enterp Theory Pract 38(1):117135

Hilmersson M (2011) Establishment of Insidership positions in institutionally distant business networks. Doctoral disseration, Linnaeus University. Linnaeus University Press

Hilmersson M (2013) The effect of international experience on the degree of SME insidership in newly opened business networks. Balt J Manag 8(4):397-415

Hilmersson M, Jansson H (2012a) International network extension processes to institutionally different markets: entry nodes and processes of exporting SMEs. Int Bus Rev 21(4):682-693

Hilmersson M, Jansson H (2012b) Reducing uncertainty in the emerging market entry process: on the relationship among international experiential knowledge, institutional distance, and uncertainty. J Int Mark 20(4):96-110

Hoang H, Antoncic B (2003) Network-based research in entrepreneurship: a critical review. J Bus Ventur 18(2):165-187

Hohenthal J, Johanson J, Johanson M (2003) Market discovery and the global expansion of the firm. Int Bus Rev 12(6):659-673

Holcombe RG (1998) Entrepreneurship and economic growth. Q J Aust Econ 1(2):45-62 
Houston FS, Gassenheimer JB (1987) Marketing and exchange. J Mark 51(4):3-18

Jennings JE, Jennings PD, Greenwood R (2009) Novelty and new firm performance: the case of employment systems in knowledge-intensive service organizations. J Bus Ventur 24(4):338-359

Johannisson B (1996) The dynamics of entrepreneurial networks. Front Entrep Res 1996:253-267

Johanson J, Mattsson LG (1988) Internationalization in industrial systems - a network approach. In: Vahlne JE, Hood N (eds) Strategies in global competition. Croom Helm, New York, pp 303-321

Johanson J, Vahlne JE (1977) The internationalization process of the firm - a model of knowledge development and increasing foreign market commitments. J Int Bus Stud 8(1):23-32

Johanson J, Vahlne JE (1990) The mechanism of internationalisation. Int Mark Rev 7(4):11-24

Johanson J, Vahlne JE (2003) Business relationship learning and commitment in the internationalization process. J Int Entrep 1(1):83-101

Johanson J, Vahlne JE (2006) Commitment and opportunity development in the internationalization process: a note on the Uppsala Internationalization Process Model. Manag Int Rev 46:165-178

Johanson J, Vahlne JE (2009) The Uppsala Internationalization Model revisited: from liability of foreignness to liability of outsidership. J Int Bus Stud 4(9):1-21

Johanson J, Wiedersheim-Paul F (1975) The internationalization of the firm-four Swedish Cases. J Manag Stud 12(3):305-323

Jones MV, Casulli L (2014) International entrepreneurship: exploring the logic and utility of individual experience through comparative reasoning approaches. Enterp Theory Pract 38(1):45-69

Kirzner I (1973) Competition and entrepreneurship. University of Chicago Press, Chicago

Kirzner IM (1997) Entrepreneurial discovery and the competitive market process: an Austrian approach. J Econ Lit 35(1):60-85

Komulainen H, Mainela T, Tahtinen J (2006) Social networks in the initiation of a high-tech firm's internationalisation. Int J Entrep Innov Manag 6(6):526-541

Kontinen T, Ojala A (2011) Network ties in the international opportunity recognition of family SMEs. Int Bus Rev 20:440-453

Levinthal DA, March JG (1993) The myopia of learning. Strateg Manag J 14(S2):95-112

Levitt B, March JG (1988) Organizational learning. Annu Rev Sociol 14(1):319-338

Lumpkin GT, Dess GG (2001) Linking two dimensions of entrepreneurial orientation to firm performance: the moderating role of environment and industry life cycle. J Bus Ventur 16(5):429-451

Madsen TK, Servais P (1997) The internationalization of born globals: an evolutionary process? Int Bus Rev 6(6):561-583

Mainela T, Puhakka V, Servais P (2014) The concept of international opportunity in international entrepreneurship: a review and a research agenda. Int J Manag Rev 16(1):105-129

McDougall-Covin P, Jones MV, Serapio MG (2014) High-potential concepts, phenomena, and theories for the advancement of international entrepreneurship research. Enterp Theory Pract 38(1):1-10

Merriam SB (1998) Qualitative research and case study applications in education. Revised and expanded from "Case Study Research in Education.". Jossey-Bass Publishers, San Francisco

Meyer KE, Estrin S (1997) Privatisation acquisition and direct foreign investment: who buys state-owned enterprises? MOCT-MOST: Econ Policy Transit Econ 7(1):159-172

Miller D, Friesen PH (1983) Strategy-making and environment: the third link. Strateg Manag J 4(3):221-235

Nahapiet J, Ghoshal S (1998) Social capital, intellectual capital, and the organizational advantage. Acad Manag Rev 23(2):242-266

Oviatt BM, McDougall PP (1997) Challenges for internationalization process theory: the case of international new ventures. MIR: Manag Int Rev 37:85-99

Pedersen T, Petersen B (1998) Explaining gradually increasing resource commitment to a foreign market. Int Bus Rev 7(5):483-501

Powell WW (1990) Neither market nor hierarchy. Res Organ Behav 12:295-336

Reid SD (1981) The decision-maker and export entry and expansion. J Int Bus Stud 12(Fall):101-112

Roberts EB (1991) Entrepreneurs in high technology: lessons from MIT and beyond. Oxford University Press, New York

Sarasvathy S, Kumar K, York JG, Bhagavatula S (2014) An effectual approach to international entrepreneurship: overlaps, challenges, and provocative possibilities. Enterp Theory Pract 38(1):71-93

Schumpeter J (1934) The theory of economic development, 1st edn. Harvard University Press, Cambridge

Schweizer R, Johanson J, Vahlne JE (2010) Internationalization as an entrepreneurial process. Int J Int Entrep 8(4):343-370

Shane SA (2004) Academic entrepreneurship: university spinoffs and wealth creation. Edward Elgar Publishing, Cheltenham 
Shane S (2012) Reflections on the 2010 AMR Decade Award: delivering on the promise of entrepreneurship as a field of research. Acad Manag Rev 37(1):10-20

Shane S, Venkataraman S (2000) The promise of entrepreneurship as a field of research. Acad Manag Rev 25(1):217-226

Sharma DD, Blomstermo A (2003) The internationalization process of born globals: a network view. Int Bus Rev 12(6):739-753

Shepherd DA, Ettenson R, Crouch A (2000) New venture strategy and profitability: a venture capitalist's assessment. J Bus Ventur 15(5):449-467

Sydow J, Schreyögg G, Koch J (2009) Organizational path dependence: opening the black box. Acad Manag Rev 34(4):689-709

Tripsas M, Gavetti G (2000) Capabilities, cognition, and inertia: evidence from digital imaging. Strateg Manag J 21(10-11):1147-1161

Tsang EW (2002) Acquiring knowledge by foreign partners from international joint ventures in a transition economy: learning-by-doing and learning myopia. Strateg Manag J 23(9):835-854

Uzzi B (1996) The sources and consequences of embeddedness for economic performance of organizations: the network effect. Am Sociol Rev 61(4):674-698

Venkataraman S (1997) The distinctive domain of entrepreneurship research: an editor's perspective. In: Katz J, Brockhaus R (eds) Advances in entrepreneurship, firm emergence, and growth, vol 3. JAI Press, Greenwich, pp 119-138

Wilkinson IF, Young LC (2005) Toward a normative theory of Normative Marketing Theory. Mark Theory 5(4):363-396

Yin RK (2009) Case study research: design and methods. Sage, Los Angeles

Zahra SA, Ireland RD, Hitt MA (2000) International expansion by new venture firms: international diversity, mode of market entry, technological learning, and performance. Acad Manag J 43(5):925-950 